ring-fenced for mental health services. Typically, most resources are provided to the psychiatric hospitals and outpatient units to cover the costs of medication and staff and so on. Extra funding may, however, come from both nongovernmental organisations and charities supported by the Church.

\section{Professional training}

Formal academic training involves 5 years of general medicine plus 3 years of specialisation in psychiatry. This involves placements in city-based hospitals as well as in more rural areas of the country. The first stage of training is awarded by the university in which the training was completed; further specialist psychiatric training is awarded by the Sociedad Boliviana de Psychiatria (see http://www. psiquiatriabolivia.org).

\section{Prevalence of psychiatric conditions}

The principal conditions for which patients are admitted to specialised psychiatric centres in Bolivia (Rivera, 2008a) include: schizophrenia/schizotypal disorders $(28.0 \%$ of admissions); substance misuse (28.0\%); organic mental disorders (including somatic disorders) (17.5\%); mood disorders (13.5\%); neurotic disorders secondary to stress
(6.9\%); personality disorders (2.9\%); intellectual disability $(1.7 \%)$; and anorexia nervosa (0.2\%). Substance misuse involves alcohol in $88 \%$ of cases and drugs (mainly cocaine and marijuana) in $7 \%$; the remaining $5 \%$ involves polydrug misuse. Overall, the tenth commonest reason for any doctor's consultation in Bolivia is depression.

\section{References}

Becht, D. (1998) Kallawayas: The nomadic medicine men of Bolivia. At http://www.paho.org/English/DPI/Number5_article4.htm (accessed 20 June 2011).

Rivera, G. (2008a) The mental health in Bolivia (draft version). At http://www.scribd.com/doc/45653836/The-Mental-Health-in-Bolivia (accessed 20 June 2011).

Rivera, G. (2008b) Panorama de la salud mental en Bolivia. At http:// www.psiquiatriasur.cl/portal/modules/wfdownloads/singlefile. php? cid =2\&lid=303 (accessed 20 June 2011).

Rocha, M. (2008) Informe de la Evaluacion de Salud Mental en Bolivia Usando el Instrumento de la Evaluacion de los Sistemas de Salud Mental de la OMS. WHO. Available from: http://www.who.int/mental health/bolivia_who_aims_report.pdf (accessed 20 June 2011).

United Nations Development Programme (2010) Human Development Report. At http://hdr.undp.org/en/reports/global/hdr2010 (accessed 20 June 2011).

World Health Organization (2008) Sistema de Salud Mental en Bolivia. WHO. At http://www.who.int/mental health/bolivia_who_aims report.pdf (accessed 20 June 2011).

World Health Organization (2011) Human Resources for Mental Health: Workforce Shortages in Low- and Middle-Income Countries. At http:// whqlibdoc.who.int/publications/2011/9789241501019_eng.pdf (accessed 20 June 2011).

\title{
Mental health in Somalia
}

\section{Rebecca J. Syed Sheriff, ${ }^{1}$ Massimiliano Reggi, ${ }^{2}$ Abdirizak Mohamed, ${ }^{3}$ Farhan Haibe, ${ }^{4}$ Susannah Whitwell ${ }^{5}$ and Rachel Jenkins ${ }^{6}$}

'King's College London, Institute of Psychiatry, London, UK, email rebecca_syed@hotmail.com; ${ }^{2}$ Gruppo per le Relazioni Transculturali, Milan, Italy; ${ }^{3}$ General Assistance and Voluntary Organisation (GAVO), Hargeisa, Somaliland; ${ }^{4}$ General Assistance and Voluntary Organisation (GAVO), Hargeisa, Somaliland; ${ }^{5}$ South London and Maudsley NHS Foundation Trust,

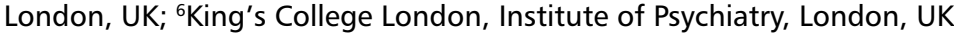

\begin{abstract}
omalia, in the Horn of Africa, suffers violence, political instability and high mortality rates. The recent major drought in Somalia led to what was termed the worst humanitarian disaster in the world. In July 2011 it was reported that nearly 60000 people had entered into Kenya from Somalia already that year, including 1300 new arrivals every day to the Dadaab refugee camp, described as 'the largest, most congested and one of the most remote refugee camps in the world' (see http://www. unhcr.org/4e204b1e9.html). The drought along with mass migration into such poor conditions are likely to have
\end{abstract}

significant short- and long-term mental health consequences for the populations involved.

Somalia comprises Somaliland, Puntland and South Central Somalia (Somalia-SC). Somaliland, in the north, declared independence from Somalia in 1991, with resulting relative peace, stability and development, but is yet to be internationally recognised. The Puntland State of Somalia, in the centre (including the Horn itself) was established in 1998 by traditional and political leaders (Ministry of Planning and Statistics, 2003). Most of the violence is now concentrated in Somalia-SC, where there is considerable destruction of the infrastructure. 
The population of Somalia is estimated to be around 9.3 million, of whom 65\% are nomadic (United Nations Department of Economic and Social Affairs, 2010). Some 1.5-2.2 million are in Puntland (Ministry of Planning and Statistics, 2003; Puntland Development Research Center, 2004) and 2-3.5 million are in Somaliland (Jarabi, 2007), with the remainder in Somalia-SC. There are 139000 internally displaced persons in Puntland, 67000 in Somaliland and 1259000 in Somalia-SC (see http://www.unhcr.org/refworld/ docid/4d3574d42.html). The vast majority of Somalis are Sunni Muslim. Gross domestic product (GDP) per capita was US\$298 in 2008 .

There are not yet any national epidemiological studies of mental illness in Somalia. However, in a community study in Hargeisa, Somaliland, in which 4854 randomly selected persons were screened, the rate of severe disability due to mental disorders was $8.4 \%$ among adult males. Exposure to conflict and heavy khat use were correlated with psychotic symptoms (Odenwald et al, 2005). High rates of female genital mutilation (98\%) (Gulaid, 2008) as well as suspected high rates of domestic and gender-based violence may prove potent risk factors for mental illness in women.

\section{Mental health legislation and policy}

There is no overarching mental health policy or legislation in Somalia. In Somalia-SC national mental health 'focal points' (health service providers nominated by the Ministry of Health) are authorised to provide mental health services (World Health Organization, 2009a) and psychotropic medicines are included on the essential medicines list. In Somaliland mental health is included in the 1999 National Health Policy (a precursor to mental health legislation) and in the essential package of health services (EPHS) at tertiary (referral hospital) level. The Puntland Agency for Social Welfare (PASWE), an autonomous semi-governmental agency, was created to 'develop and promote policies and standards toward protecting and assisting the most vulnerable people' in Puntland (see http://paswe.org).

\section{Health funding}

There has been a fivefold increase in external funding for the health sector in Somalia over the past decade (Capobianco \& Naidu, 2001) but the performance of the health sector remains poor and less than half the population has access to adequate healthcare (United Nations Development Programme, 2001). In Somalia-SC there is no public budget and no public financial management or accountability: most health-related activities are run by private or public institutions or through the unofficial out-of-pocket system (World Health Organization, 2009a). The health budget in Somaliland is only $\$ 750000$. In Puntland, the education, health and water sectors combined receive less than $5 \%$ of the government budget. According to government officials, 'resources available to the Ministry are limited and its role has been primarily to coordinate the activities of international agencies and NGOs' (Ministry of Planning and Statistics, 2003).

\section{Mental health services}

The civil war destroyed much of Somalia's healthcare infrastructure, which, in addition to the migration or death of health personnel, means that access to healthcare is greatly compromised (Leather et al, 2006).

Traditional and religious healers (mostly herbalists and faith healers) are the mainstay of the general population's access to mental healthcare. There are no data available on their numbers or training, or on patient outcomes, and there is concern that some practices are harmful. Families often feel they have no option other than to restrain people with severe mental illness in homes or local jails (which can occur without a court hearing).

The mental health of patients has often severely deteriorated by the time they are brought to hospital. For example, the onset of mental illness among patients of the Bosaso Mental Health Department (MHD) in Puntland is on average 3.5 years before their first visit. At the time of their first clinic visit, some $85 \%$ of patients have been visited at least once by a Koranic healer or by a traditional healer. During the first year of opening of the MHD almost 30\% of patients were brought in physically chained (according to the MHD database). Psychotropic drugs are unregulated and family members often rely on the purchase of drugs directly from pharmacies.

\section{Somaliland}

There are no psychiatric staff available in general primary or secondary healthcare services, and limited psychotropic medication is available in only two of the general health facilities. Until recently there were only two public psychiatric units in Somaliland, a ward in Hargeisa Group Hospital (HGH) (110 beds) and Berbera Mental Hospital (42 beds) both staffed by auxiliary nurses. The unit at $\mathrm{HGH}$ has input from a post-intern doctor and is supported by an Italian nongovernmental organisation (NGO), Gruppo per le Relazioni Transculturali (GRT), and a local NGO, the General Assistance and Volunteer Organisation (GAVO), which provide salary support, medication, supervision and training. The unit in Berbera is supported by GAVO and has access to a general doctor (Syed Sheriff et al, 2010).

The newly opened out-patient unit in Boroma is supported by Amoud University and run by one of the former KTSP mental health representatives (see below), and an out-patient clinic and day clinic in Burao for children with intellectual disability is supported by a local NGO.

There is a growing number of privately owned, unregulated mental health service providers which have in-patient and out-patient facilities with pharmacies in Somaliland (World Health Organization, 2009b).

\section{Puntland}

A ten-bed mental health facility was opened in 2003 in Bosaso. GRT has supported the training of eight staff, including one doctor, the provision of free mental healthcare to in-patients and out-patients, home visits and free medication. In Garowe there is a facility run by a local organisation for 39 male patients that has some nursing staff and sporadic visits from a doctor. There is also a psychological out-patient department run by PASWE. PASWE also runs a 22-bed facility for women staffed by four nurses in Galkayo. 


\section{Somalia-SC}

There are five public facilities with mental health services in Somalia-SC, two in Mogadishu (53 beds and 170 beds), one in Jalalaqsi (15 beds and an out-patient department), one in Merka providing basic mental health services from the general hospital, and one in Baidoa (35 beds), all staffed by nurses and volunteers with ad hoc mental health training by the World Health Organization (2009a).

\section{Psychiatric training}

The Somaliland health sector is largely unregulated and health professionals unlicensed. With the exception of the newly qualified, most doctors in Somaliland work exclusively in the private sector and have not received continuing professional development (Syed Sheriff et al, 2010).

In 2000 and 2005, two medical schools opened in Somaliland, in Boroma and Hargeisa respectively, and over 50 students have graduated. A link between King's College Hospital, THET (the Tropical Health and Education Trust) and partners in Somaliland, known as KTSP (King's THET Somaliland Partnership), set up a mental health group in 2007, described elsewhere (Syed Sheriff et al, 2010), which has enabled mental health to be incorporated into undergraduate and postgraduate training. For the past 4 years mental health has been taught to final-year medical students by visiting UK psychiatrists in collaboration with the educational institutions and GAVO. The website Medicine Africa delivers distance tutorials to final-year students (see Finlayson et al, 2010). There is a project partnering medical students in Somaliland with those in the UK. Since 2009 psychiatry has been examined in medical finals, assisted by external examiners from the UK.

A 2-year internship programme provides a structured training environment for junior doctors in Somaliland. Mental health has been part of internship since late 2009, and in 2010 a continuing professional development course in psychiatry was provided by KTSP for 28 interns in Hargeisa and Boroma. Currently, regular supervision for Somaliland interns and post-interns is provided from matched UK staff via Medicine Africa. A KTSP mental health representative has been regularly selected competitively from among Somaliland interns to advocate for mental health locally, build local faculty and medical leadership, and increase the sustainability of the work of KTSP. GRT also provides periodic training by a consultant psychiatrist to the post-intern former KTSP representative working in Hargeisa Group Hospital.

In Somalia-SC the first 20 medical students since 1991 graduated in 2008 (see http://www.somalianinfo.com/ somalian-physicians.html), although less encouraging was the brutal suicide bombing attack during the diploma ceremony 1 year later.

There is no medical school in Puntland.

\section{Research}

There is no academic faculty for mental health. Limited research in mental health has been conducted by academic institutions elsewhere in the world, sometimes in collaboration with local NGOs (Odenwald et al, 2005; Reggi, 2011). A patient database was created by GRT in 2004 in the Mental Health Department, Bosaso, Puntland.

\section{Acknowledgements}

The authors acknowledge the work of Abdulkadir AbdiKalif Ali, Fatuma Hashi Farah, Maryam Hassan Dahir, Sakin Jirdeh, Deria I. Ereg, Sacad A. Walhad, Andrew Leather and the work of THET.

\section{References}

Capobianco, E. \& Naidu, V. (2001) A Decade of Aid to the Health Sector in Somalia: 2000-2009. World Bank.

Finlayson, A., Baraco, A., Cronin, N., et al (2010) An international, case-based, distance-learning collaboration between the UK and Somaliland using a real-time clinical education website. Journal of Telemedicine and Telecare, 16, 181-184.

Gulaid, U. J. (2008) The challenge of female genital mutilation in Somaliland. Finnish Journal of Ethnicity and Migration, special issue 2.

Jarabi, B. O. (2007) Review of Various Population Estimates for Somaliland, Puntland and South-Central Somalia. Independent Consultancy Mission.

Leather, A., Ismail, E. A., Ali, R., et al (2006) Working together to rebuild health care in post-conflict Somaliland. Lancet, 368, 1119-1125.

Ministry of Planning and Statistics (2003) Puntland Facts and Figures. Ministry of Planning and Statistics.

Odenwald, M., Neuner, F., Schauer, M., et al (2005) Khat use as a risk factor for psychotic disorders: a cross-sectional and case-control study in Somalia. BMC Medicine, 3, 5.

Puntland Development Research Center (2004) Draft Report on Socio-Economic Assessment in Puntland. Puntland State of Somalia.

Reggi, M. (2011) Welcome to Marqaan Station. Falliti tentativi d'emigrazione e disagio mentale nella Somalia contemporanea. In Migrazioni. Dal lato dell'Africa (ed. A. Bellagamba). Edizioni Altravista (in press).

Syed Sheriff, R. J., Baraco, A., Nour, A., et al (2010) Public-academic partnerships: improving human resource provision for mental health in Somaliland. Psychiatric Services, 61, 225-227.

United Nations Department of Economic and Social Affairs (2010) World Population Prospects: The 2010 Revision. UN-DESA. At http://esa. un.org/unpd/wpp/index.htm (accessed June 2011).

United Nations Development Programme (2001) Human Development Report for Somalia. UNDP. At http://hdr.undp.org/en/reports/national/ arabstates/somalia/Somalia_2001_en.pdf (accessed August 2011).

World Health Organization (2009a) WHO-AIMS Report on Mental Health System in Mogadishu and South/Central Somalia. WHO and Ministry of Health. At http://www.who.int/mental_health/mogadishu_ south_central_somalia_who_aims_report.pdf (accessed August 2011).

World Health Organization (2009b) WHO-AIMS Report on Mental Health System in Somaliland Region of Somalia. WHO, GAVO and Ministry of Health. At http://www.who.int/mental_health/somaliland_ who_aims_report.pdf (accessed August 2011).

New Honorary Fellows

On 30 June 2011 the College inaugurated five new Honorary Fellows:

- Professor James Louis John Appleby CBE FRCPsych

- Stuart Bell CBE

- Professor Michael Gelder FRCPsych

- Dr Pedro Ruiz

- Dr Nada Stotland MD MPH

Honorary Fellowship is one of the highest awards the Royal College of Psychiatrists can bestow on an individual. The individuals to whom Honorary Fellowship is awarded are highly distinguished and have all made tremendous contributions either to psychiatry or to mental health services in the UK and worldwide during their careers. Further information about these outstanding candidates is available on the College website (http://www.rcpsych.ac.uk). 